\title{
Differential Triggering of the Phenylpropanoid Biosynthetic Pathway Key Genes Transcription upon Cold Stress and Viral Infection in Tomato Leaves
}

\author{
Polyxeni Pappi ${ }^{1}$, Nikolaos Nikoloudakis ${ }^{2}$ D , Dimitrios Fanourakis ${ }^{3}{ }^{\mathbb{D}}$, Antonios Zambounis ${ }^{4}$, Costas Delis ${ }^{5}$ \\ and Georgios Tsaniklidis ${ }^{1, *(D)}$
}

1 Institute of Olive Tree, Subtropical Plants and Viticulture, Hellenic Agricultural Organization ‘ELGO DIMITRA', 73100 Chania, Greece; pappi@elgo.iosv.gr

2 Department of Agricultural Science, Biotechnology and Food Science, Cyprus University of Technology, Limassol 3036, Cyprus; n.nikoloudakis@cut.ac.cy

3 Laboratory of Quality and Safety of Agricultural Products, Landscape and Environment, Department of Agriculture, School of Agricultural Sciences, Hellenic Mediterranean University, Estavromenos, 71004 Heraklion, Greece; dimitrios.fanourakis82@gmail.com

4 Institute of Plant Breeding and Genetic Resources, Hellenic Agricultural Organization 'ELGO DIMITRA', Thermi, 57001 Thessaloniki, Greece; antbio@yahoo.gr

5 Department of Agriculture, University of Peloponnese, Antikalamos, 24100 Kalamata, Greece; k.delis@uop.gr

* Correspondence: tsaniklidis@elgo.iosv.gr

check for updates

Citation: Pappi, P.; Nikoloudakis, N.; Fanourakis, D.; Zambounis, A.; Delis, C.; Tsaniklidis, G. Differential Triggering of the Phenylpropanoid Biosynthetic Pathway Key Genes Transcription upon Cold Stress and Viral Infection in Tomato Leaves. Horticulturae 2021, 7, 448. https:/ / doi.org/10.3390/horticulturae7110448

Academic Editor: Yan Xu

Received: 2 October 2021

Accepted: 26 October 2021

Published: 2 November 2021

Publisher's Note: MDPI stays neutral with regard to jurisdictional claims in published maps and institutional affiliations.

Copyright: (c) 2021 by the authors. Licensee MDPI, Basel, Switzerland. This article is an open access article distributed under the terms and conditions of the Creative Commons Attribution (CC BY) license (https:/ / creativecommons.org/licenses/by/ $4.0 /)$.

\begin{abstract}
Plants develop a plethora of defense strategies during their acclimation and interactions with various environmental stresses. Secondary metabolites play a pivotal role in the processes during stress acclimation, therefore deciphering their relevant responses exchange the interpretation of the underlying molecular mechanisms that may contribute to improved adaptability and efficacy. In the current study, tomato plants were exposed to short-term cold stress $\left(5^{\circ} \mathrm{C}\right.$ for $16 \mathrm{~h}$ ) or inoculated (20 d) with either Cucumber Mosaic Virus (CMV) or Potato Virus Y (PVY). Responses were recorded via the assessments of leaf total phenolic (TP) content, total flavonoid (TF) levels, and phenylalanine ammonia-lyase (PAL) enzyme activity. The transcription of the gene families regulating the core phenylpropanoid biosynthetic pathway (PBP) at an early (PAL, cinnamic acid 4-hydroxylase, 4coumarate-CoA ligase) or late (chalcone synthase and flavonol synthase) stage was also evaluated. The results showed that cold stress stimulated an increase in TP and TF contents, while PAL enzyme activity was also elevated compared to viral infection. Besides genes transcription of the enzymes involved in the core PBP was mostly induced by cold stress, whereas transcription of the genes regulating flavonoid biosynthesis was mainly triggered by viral infection. In conclusion, abiotic and biotic stressors induced differential regulation of the core PBP and flavonoid biosynthetic metabolism. Taking the above into consideration, our results highlight the complexity of tomato responses to diverse stimuli allowing for better elucidation of stress tolerance mechanisms at this crop.
\end{abstract}

Keywords: Cucumber Mosaic Virus; flavonoids; biotic stress; abiotic stress; phenolics; phenylalanine ammonia-lyase; Potato Virus Y; Solanum lycopersicum

\section{Highlights}

- Phenolic, flavonoid contents, and PAL enzyme activity were elevated after biotic and abiotic stresses.

- Phenolic moieties were generally more enhanced by cold stress as compared to viral infection.

- $\quad$ The transcription of most genes encoding for enzymes regulating both the core PBP and flavonoid synthesis was affected by biotic and abiotic stresses.

- $\quad$ The former was mainly triggered by cold stress, whereas the latter by viral infection. 


\section{Introduction}

In planta, L-phenylalanine serves as the biosynthesis precursor of a range of secondary metabolites, which are centrally involved in fundamental physiological and developmental processes. These metabolites are regulated by complex biosynthetic routes via the phenylpropanoid biosynthetic pathway (PBP; [1]). Regardless of their structural differences and physiological roles, all PBP products share the first three conversion steps (termed general PBP), which are mediated by three enzymes (Figure 1). Phenylalanine ammonia-lyase enzyme (PAL; EC 4.3.1.24) is at the interface between primary and secondary metabolism. It is the initial and rate limiting PBP step that converts L-phenylalanine to cinnamic acid. Cinnamic acid is then converted to $p$-coumaric acid by cinnamic acid 4-hydroxylases activity (C4H; EC:1.14.14.91). By employing $p$-Coumaric acid as substrate, 4-coumarate-CoA ligases (4CL; EC 6.2.1.12) (Supplementary Figure S1) not only generate $p$-Coumaric CoA thioesters but also intervene in later metabolic pathway reactions by providing activated thioester substrates. In this way, 4CL orchestrates the metabolic shifting towards the production of caffeic, sinapic, and ferulic acids. Therefore, 4CL controls the carbon flux towards diverse PBP products, including flavonoids, polyphenols, lignin, coumarin, and suberin [2-5]. Besides 4CL, $p$-Coumaric acid is the substrate in one of the salicylic acid biosynthetic routes, which is critical in orchestrating stress-induced responses [6].

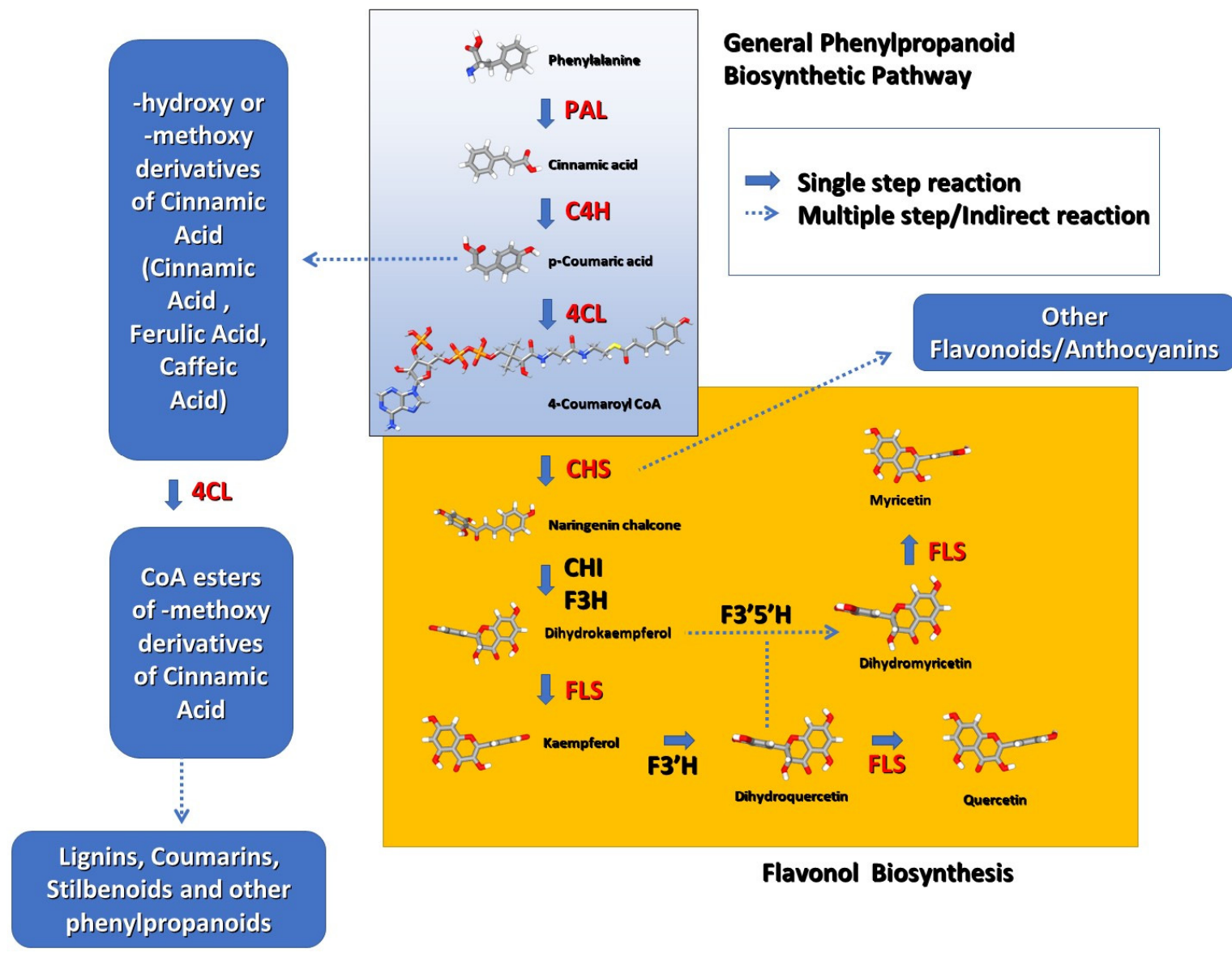

Figure 1. General phenylpropanoid biosynthetic pathway (consisting of phenylalanine-ammonia lyase (PAL), cinnamic acid 4-hydroxylase $(\mathrm{C} 4 \mathrm{H})$, and 4-coumarate-CoA ligase (4CL) enzymes) preceding flavonoid biosynthesis (mediated via chalcone synthase (CHS) and flavonol synthase (FLS) enzymes).

At a later stage, the production of an array of flavonoid substrates with variable phenolic structures is mainly regulated by chalcone synthases (CHS; EC 2.3.1.74) (Supplementary Figure S2) and flavonol synthases (FLS; EC 1.14.11.23) [7] (Figure 1). Flavonoids are the largest class of phenylpropanoids spanning to more than 8000 known molecules [8]. This 
chemical class shares a similar $\mathrm{C}_{6}-\mathrm{C}_{3}-\mathrm{C}_{6}$ backbone, while relevant bioactive properties mainly depend on specific secondary structural differences [7,9]. In plants, flavonols occur as aglycones, glycosides, or methylated derivatives. They exhibit strong antiviral activity and are commonly used in medicine (reviewed in Zakaryan et al. [10]).

It is well known that the phenylpropanoid biosynthetic pathway is a cross response to several environmental perturbations (reviewed in Šamec et al. [11]), and is generally upregulated under either abiotic or biotic stress. In plants facing adverse conditions, the accumulation of phenolic compounds through activation of this pathway has been generally associated with enhanced stress tolerance [12-14]. The induced resistance has been related to the wide range of polyphenol functions, principally consisting of reactive oxygen species (ROS) scavenging ability (thus oxidative stress alleviation) and strong antimicrobial activity. In addition, polyphenols serve other key roles. For instance, they act as signaling molecules controlling systemic physiological responses for the alleviation of the stress-induced metabolic deregulation [15-20].

Apart from the large amount of accumulated evidence, further research is required to investigate the expression of genes encoding for the regulatory enzymes of the phenolics pathways, in relation to stresses of differential nature (i.e., abiotic or biotic). Thus, the aim of this work was to estimate the magnitude of the effects caused by cold stress versus viral infection on total phenolic (TP) level, total flavonoid (TF) content, and PAL enzyme activity in tomatoes. Tomato is an economically important horticultural crop that is widespread globally and faces a plethora of diverse stresses during cultivation. Alongside, a meticulous transcription analysis across isoforms of gene families coding for PAL, $\mathrm{C} 4 \mathrm{H}$, and 4CL (PBP metabolism) as well as for CHS, and FLS (flavonoid/flavonol biosynthesis) was conducted. Such comparisons are insightful regarding the mechanisms that govern stress alleviation responses, and thus can contribute to the deciphering of stress tolerance interplay. This study further highlights that the nature and the magnitude of secondary metabolism upregulation depends on the type of stress. Taking this diverse upregulation into consideration is of high importance for engineering stress tolerance in horticultural crops.

\section{Materials and Methods}

\subsection{Plant Material and Growing Conditions}

In this study, a tomato F1 hybrid ("Elpida"), which is widely cultivated in Greece, was employed. It is rather insensitive to temperature drops, without documented tolerance in CMV and PVY viruses. Rooted plantlets were transferred to $1.16 \mathrm{~L}$ pots containing a mixture of peat and perlite (9:1, v/v; Meegaa substrates BV, Rotterdam, The Netherlands), supplemented at the beginning of cultivation with $2.5 \mathrm{~g}$ chemical fertilizer $\left(\mathrm{N}: 4 ; \mathrm{P}_{2} \mathrm{O}_{5}\right.$ : 14; $\mathrm{K}_{2} \mathrm{O}: 8+$ micronutrients) per pot. Plants were cultivated in a walk-in climate chamber $(1 \times \mathrm{w} \times \mathrm{h}=3.0 \mathrm{~m} \times 2.5 \mathrm{~m} \times 2.2 \mathrm{~m})$. The air temperature was set to $25^{\circ} \mathrm{C}$, and relative air humidity to $50 \%$. The light level was set at $200 \mu \mathrm{mol} \mathrm{m}{ }^{-2} \mathrm{~s}^{-1}$ photosynthetic photon flux density at the top of the plant canopy for $12 \mathrm{~h}$ per day. Potting-media moisture was maintained by regular watering.

Plants at the same developmental stage and with uniform architecture were selected for applying the treatments. At $23 \mathrm{~d}$ of cultivation, one set of plants was mechanically inoculated (procedure described below) with CMV, and another set with PVY. The remaining plants were mock-inoculated using phosphate buffer. Plants were cultivated for another $20 \mathrm{~d}$ under the same conditions (described above). At that time, plants were at the vegetative phase (thus before anthesis). Then, one set of CMV-infected plants (1), one set of PVY-infected plants (2), and one set of mock-inoculated plants (3) were exposed to $5{ }^{\circ} \mathrm{C}$ for $16 \mathrm{~h}$ under darkness (cold stress treatment) as described in [21]. The first two treatments represent combined biotic and abiotic stress, which occurred in sequence. The third treatment represents abiotic stress (Supplementary File Figure S3).

The next day (i.e., $44 \mathrm{~d}$ of cultivation, and $21 \mathrm{~d}$ post inoculation), sampling was performed. At that time, treatments did not alter plant phenotype. Namely, plants were free of viral infection or cold stress visible symptoms, while above-ground plant biomass, 
stem length (from the root-shoot junction to the apical meristem), and leaf photosynthetic pigment (chlorophyll, carotenoids) content was not significantly affected by the treatments (Supplementary Tables S1-S3).

Young, fully expanded leaves were sampled. Herbal material was collected, flashfrozen in liquid nitrogen, and immediately transferred to a freezer $\left(-80^{\circ} \mathrm{C}\right)$ for storage.

\subsection{Mechanical Inoculation of $C M V$ and $P V Y$}

As live virus reference strains, leaves sampled from infected plants were employed. For CMV, the infected plant was Nicotiana benthamiana Domin, while for PVY (necrotic strain group N) it was a naturally infected potato plant (Solanum tuberosum L.). The N. benthamiana plant was tested for the presence of Tomato Spotted Wilt Virus (TSWV) [22] and the infected potato plant was also tested for the presence of TSWV, CMV [23], Potato Virus $X$ (PVX detection kits; Boehringer, Mannheim, Germany) and viruses belonging to the genus Tobamovirus [24], and none of these viruses were detected.

For the inoculate preparation, leaf tissues were squashed in phosphate buffer $(\mathrm{pH} 7.0)$, and then mechanically inoculated onto carborundum-dusted leaves of tomato plants, at the time stated above. For negative control, leaves were treated with carborundumdusted/phosphate buffer solution. For each plant individually, the successful infection was verified by a reverse-transcription polymerase chain reaction (RT-PCR) by using appropriate primers $[23,25]$.

\subsection{TP Content, TF Content, and PAL Enzyme Activity}

The assays of TP, TP, and PAL activity were performed as recently reported in Tsaniklidis et al. [21]. The extraction for both TP and TF was performed by homogenizing frozen leaves with $80 \%$ acetone $(v / v)$ in deionized water $\left(3 \mathrm{~mL} \mathrm{~g}^{-1}\right.$ tissue) with mortar and pestle. The homogenate was transferred in Eppendorf tubes, placed in a cold super-sonic bath under darkness ( $3 \mathrm{~min})$, and then centrifuged $(6500 \times g$ for $5 \mathrm{~min})$. The supernatant was removed and stored. The extraction process (as stated above) was repeated three times. The combined extracts were used for both TP and TF analyses after complete evaporation in an oven $\left(35^{\circ} \mathrm{C}\right.$ for $\left.48 \mathrm{~h}\right)$ and re-dissolving in $1.5 \mathrm{~mL}$ distilled water.

Leaf TP concentration was estimated using the Folin-Ciocalteu colorimetric method [26] with minor modifications, as indicated below. Briefly, $0.2 \mathrm{~mL}$ of the diluted extract with distilled water (1:2) was added into a tube containing $0.2 \mathrm{~mL}$ Folin-Ciocalteu reagent (Sigma-Aldrich, Saint Lewis, MI, USA) and $2.6 \mathrm{~mL}$ deionized water. After stirring, the tube was stored at room temperature $\left(25^{\circ} \mathrm{C}\right.$ for $\left.6 \mathrm{~min}\right)$ in darkness. Then, $2 \mathrm{~mL} \mathrm{Na}_{2} \mathrm{CO}_{3}$ $(7 \%, w / v)$ were added to the mixture and the absorbance was measured at $750 \mathrm{~nm}$ using a spectrophotometer (Mapada UV-1800; Shanghai. Mapada Instruments Co., Ltd., Shanghai, China), after incubation at room temperature $\left(25^{\circ} \mathrm{C}\right.$ for $\left.90 \mathrm{~min}\right)$ in darkness. The results were expressed as gallic acid equivalents on a fresh weight basis.

Leaf TF content was assayed using the aluminum chloride colorimetric method [27]. Rutin was used as a standard to create the calibration curve. One milliliter of leaf extract was mixed with $0.2 \mathrm{~mL}$ of $10 \%(w / v) \mathrm{AlCl}_{3}$ (Merck, Darmstadt, Germany) solution in water, $0.2 \mathrm{~mL} 1 \mathrm{M}$ potassium acetate, and $5.6 \mathrm{~mL}$ water. The mixture was incubated at room temperature $\left(25^{\circ} \mathrm{C}\right.$ for $\left.45 \mathrm{~min}\right)$, followed by the measurement of absorbance at $415 \mathrm{~nm}$ using a spectrophotometer against a blank.

PAL activity was performed as described in Assis et al. [28]. Crude enzymes were extracted from $1 \mathrm{~g}$ of frozen powdered tissue in $5 \mathrm{~mL}$ of $100 \mathrm{mM}$ potassium phosphate buffer (pH 7.8), containing $0.1 \mathrm{~g}$ polyvinylpolypyrrolidone (PVP) and after vigorous vortex. For PAL enzyme activity, the extract $(200 \mu \mathrm{L})$ was added to $2 \mathrm{~mL}$ of $0.01 \mathrm{M}$ borate buffer (pH 8.7) and $1 \mathrm{~mL}$ of $0.02 \mathrm{M} \mathrm{L-phenylalanine} \mathrm{(Sigma-Aldrich,} \mathrm{Saint} \mathrm{Lewis,} \mathrm{MI,} \mathrm{USA)}$ dissolved in $0.01 \mathrm{M}$ borate buffer ( $\mathrm{pH} 8.7)$. Absorbance $(290 \mathrm{~nm}$ ) was measured using a spectrophotometer at 0,30 , and $60 \mathrm{~min}$ following incubation at room temperature $\left(25^{\circ} \mathrm{C}\right)$. 


\subsection{RNA Extraction and Real-Time PCR}

Total RNAs were extracted from leaf tissue by using the method described in Maliogka et al. [29]. Briefly, tissue was grounded $(1 / 10, w / v)$ in a "lysis buffer" (8 M GuHCl, $25 \mathrm{mM}$ EDTA, 1\% Sarcosyl, 2\% Triton X-100, $25 \mathrm{mM}$ sodium citrate, $0.2 \mathrm{M}$ sodium acetate, $\mathrm{pH}$ adjusted to 5.2 with acetic acid). The lysate was incubated $\left(65{ }^{\circ} \mathrm{C}\right.$ for $\left.10 \mathrm{~min}\right)$ and then centrifuged $(16,000 \times g$ for $10 \mathrm{~min})$. Then, $500 \mu \mathrm{L}$ of the supernatant were transferred to a new tube and $625 \mu \mathrm{L}$ of absolute ethanol was added (to obtain $55.5 \%$ final concentration). Then, the mixture flowed through a silica column (FT-2.0 Filter-Tube Spin-Column System, G. Kisker GbR, Steinfurt, Germany) by centrifugation $(1500 \times g$ for $10 \mathrm{~min})$. The column was washed once with $700 \mu \mathrm{L}$ "wash buffer 1" (4 M GuHCl, $25 \mathrm{mM}$ Tris-HCl pH 6.6, and 60\% ethanol) and twice (700 and $400 \mu \mathrm{L}$, respectively) with "wash buffer 2" (2 mM Tris- $\mathrm{HCl} \mathrm{pH}$ $7.0,20 \mathrm{mM} \mathrm{NaCl}$, and $80 \%$ ethanol) by centrifugation $(8000 \times g$ for $1 \mathrm{~min})$. RNA was finally recovered in $70 \mu \mathrm{L}$ of preheated $\left(80{ }^{\circ} \mathrm{C}\right)$ nuclease-free elution buffer $(10 \mathrm{mM}$ Tris- $\mathrm{HCl}$, $\mathrm{pH}$ 8.0). Afterward, the total RNA was treated with DNAase I (Thermo Fisher Scientific, Waltham, MA, USA), and inactivation of DNAse was performed with heating $\left(74^{\circ} \mathrm{C}\right)$. The absence of genomic DNA was verified with qPCR using primers of the housekeeping gene $U B Q$. The $U B Q$ gene was used as a reference, while the negative control for each treatment was used for calibration and calculations. The gene expression patterns were validated using the expression of Solanum Lycopersicon Actin gene. cDNA synthesis was performed with the Superscript II cDNA synthesis kit (Thermo Fisher Scientific, Waltham, MA, USA) according to the manufacturer's instructions. The resulting first-strand cDNA was normalized for the expression using $U B Q$ primers (Supplementary Table S4). qPCR experiments were performed with the use of the PowerUp ${ }^{\mathrm{TM}} \mathrm{SYBR}^{\circledR}$ Green Master Mix (Thermo Fisher Scientific, Waltham, MA, USA) with a QuantStudio 3 Real-Time PCR System (Thermo Fisher Scientific, Waltham, MA, USA). The relative quantification of gene expression was performed as described in Tsaniklidis et al. [21]. For all samples, qPCR reactions were performed in triplicate.

\subsection{Phylogenetic Analysis of 4CL and CHS Proteins}

The phylogenetic analysis of the 4CL and CHS proteins was performed using the online software tools provided by the Laboratory of Information technology and Microelectronics of Montpellier (www.phylogeny.fr, accessed on 14 June 2021) [30].

\subsection{Statistical Analysis}

The experimental design consisted of three separate biological replicates (across all measurements), which were created after the virus detection at individual plants by random pooling of five plants per treatment. Each biological replicate (five bulked plants) was analyzed three times (nine total replicates), while qPCR was repeated twice (six total replicates). The statistical significance across treatments was inferred employing a parametric One-Way Analysis of variance (ANOVA) and the 'ggpubr' Package as implemented in the R Studio Version 1.1.463/R 3.6.1. Tests for normality are provided in Supplementary File S1.

\section{Results}

\subsection{TP Content, TF Content, and PAL Enzyme Activity}

Cold stress or viral infection (CMV or PVY) stimulated an increase in leaf TP level, TF content, and PAL enzyme activity (Figure 2). This increase was more prominent in plants exposed to cold stress, as compared to the virus-infected plants (Figure 2).

Combined biotic (CMV or PVY) and abiotic (cold) stress induced an increase in leaf TP and TF levels similar to abiotic stress alone (Supplementary File S2). Instead, PAL activity was not significantly affected by combined biotic and abiotic stress (Supplementary File S2). 

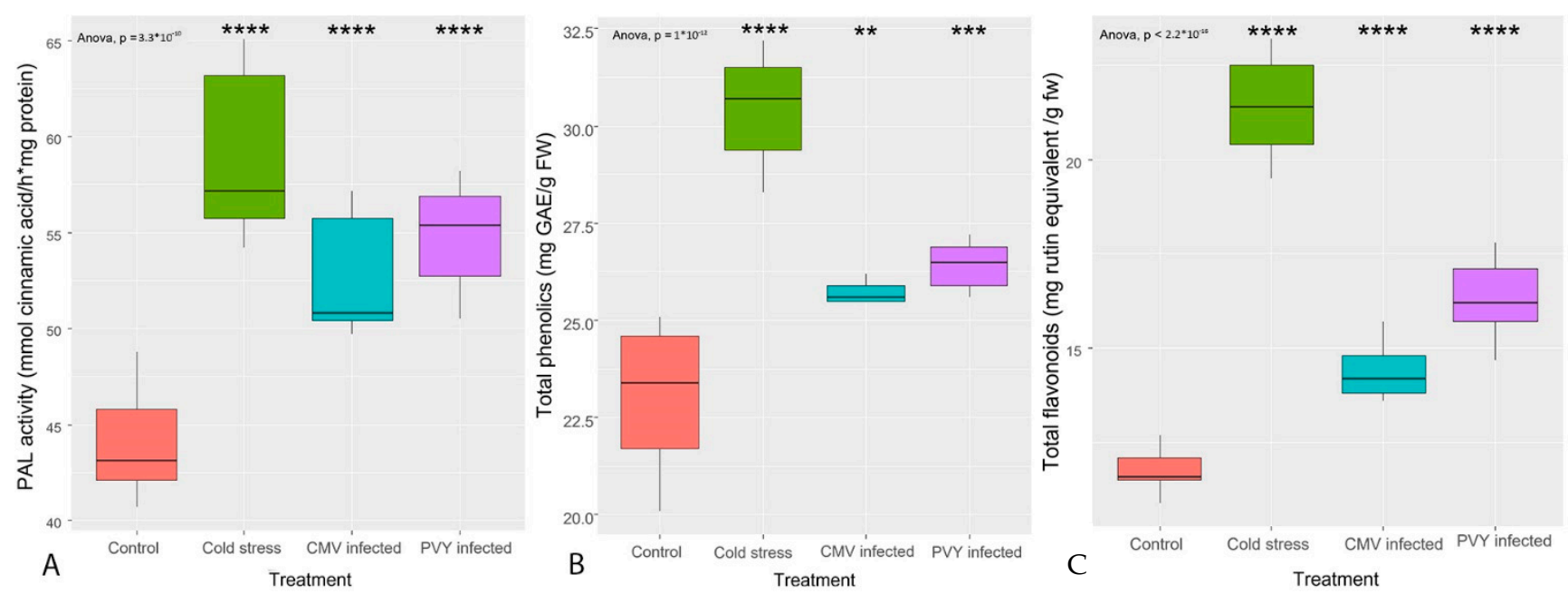

Figure 2. Phenylalanine ammonia-lyase (PAL) enzyme activity (A), total phenolic level (B), and total flavonoid content (C) of tomato leaves (cv. Elpida) following plant exposure to cold stress ( ${ }^{\circ} \mathrm{C}$ for $16 \mathrm{~h}$ ) or inoculation (20 d) with either cucumber mosaic virus (CMV) or potato virus Y (PVY). Control and cold-stressed plants were mock-inoculated. Significant differences were determined by one-way ANOVA comparisons $(p \leq 5 \%)$. Signif. codes: ns: non-significant; $0.05:{ }^{*} ; 0.01:{ }^{* *}$; $0.001:^{* * *} ; 0:{ }^{* * * *}$.

\subsection{Transcription of the Genes Regulating the General PBP Pathway (PAL, C4H, 4CL)}

The core PBP biosynthetic activity is mainly mediated by three enzymes $(\mathrm{PAL}, \mathrm{C} 4 \mathrm{H}$, and $4 \mathrm{CL}$ ). The transcription of genes encoding for these three enzymes was evaluated. Upon cold stress or viral infection (CMV or PVY), the genes coding for both PAL and C4H were generally upregulated (Figure 3). This increase was consistently more prominent following exposure to cold stress, as compared to viral infection (Figure 3).
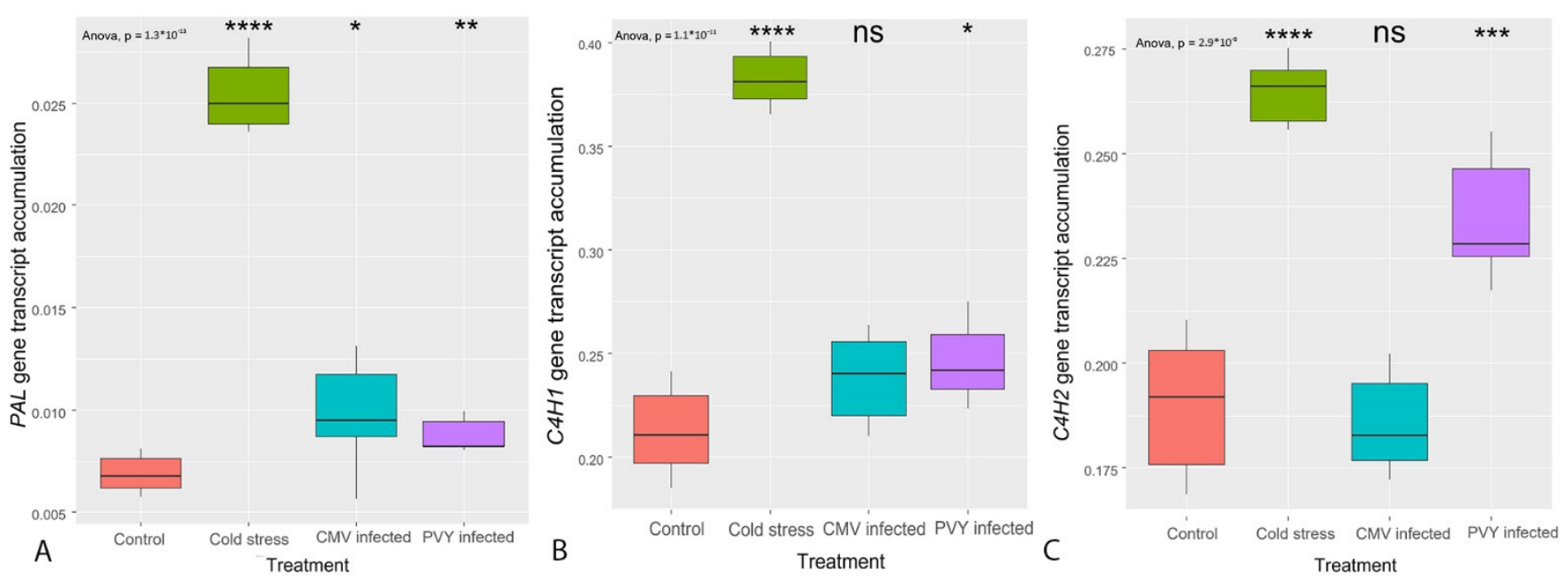

Figure 3. Transcription of the genes encoding for phenylalanine ammonia-lyase (PAL) (A), and cinnamic acid 4-hydroxylase (C4H1, C4H2) (B and C, respectively) enzymes of tomato leaves (cv. Elpida) following plant exposure to cold stress $\left(5^{\circ} \mathrm{C}\right.$ for $16 \mathrm{~h}$ ) or inoculation ( $20 \mathrm{~d}$ ) with either cucumber mosaic virus (CMV) or potato virus $Y$ (PVY). Significant differences were determined by one-way ANOVA comparisons $(p \leq 5 \%)$. Signif. codes: ns: non-significant; $0.05:{ }^{*} ; 0.01:{ }^{* *} ; 0.001:{ }^{* * *} ; 0:{ }^{* * *}$.

Combined biotic (CMV or PVY) and abiotic (cold) stress stimulated C4H gene coding in a fashion similar to cold stress alone (Supplementary File S2). For PAL genes, instead, this trend was evident for CMV but not for PVY (Supplementary File S2).

Cold stress or viral infection (CMV or PVY) generally increased the transcription in the majority of the isoforms encoding for 4CL (Figure 4). In most cases, the noted up-regulation 
was more pronounced following exposure to cold stress, as compared to viral infection (Figure 4). Nonetheless, distinctive discrepancies were apparent in the transcription of different isoforms. The response to a stimulus of identical nature (i.e., the two-virus species) was also occasionally differential.

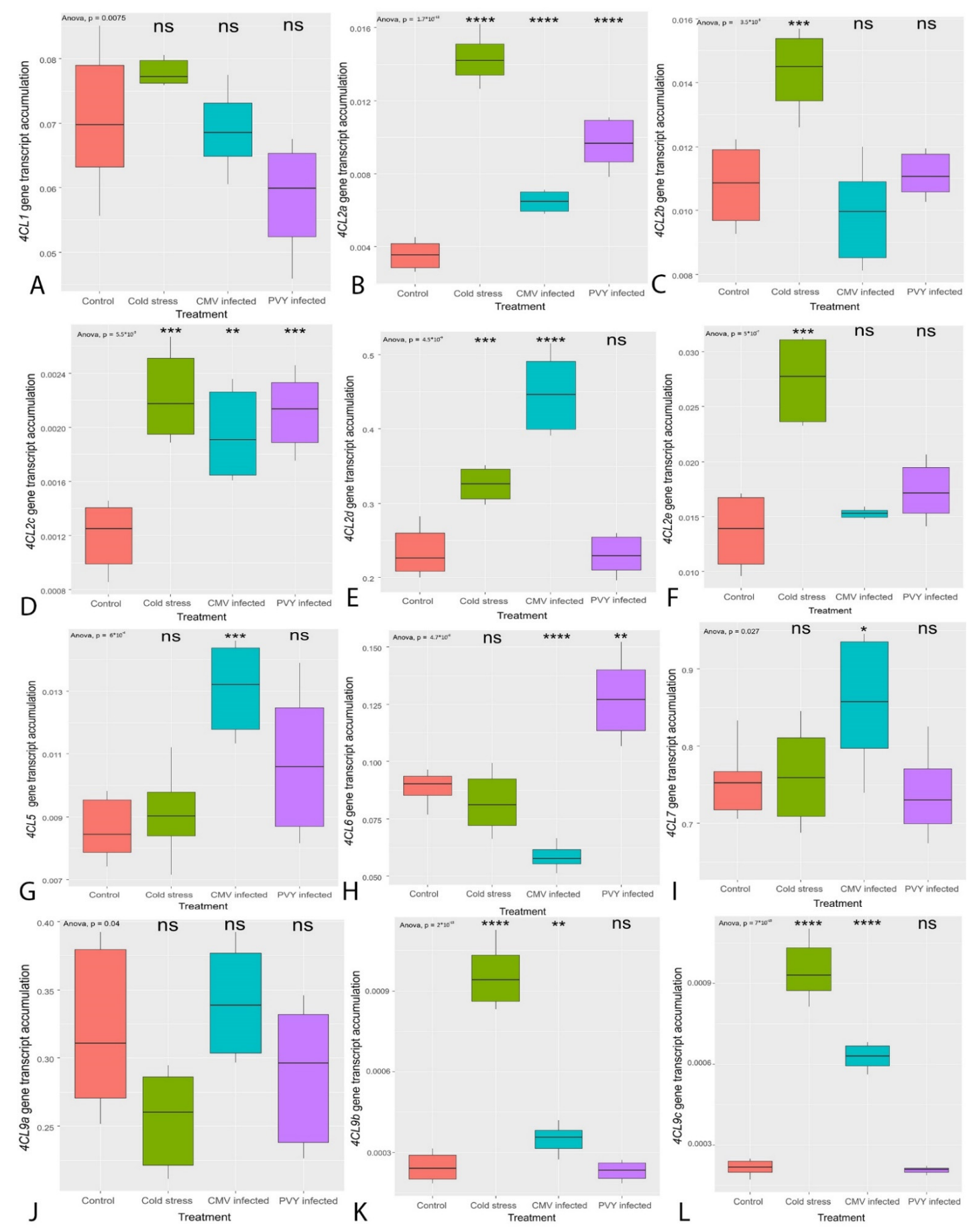

Figure 4. Transcription of the genes encoding for 4-coumarate-CoA ligase (4CL) isoenzymes ((A): 4CL1, (B): 4CL2a, (C): 4CL2b, (D): 4CL2c, (E): 4CL2d, (F): 4CL2e, (G): 4CL5, (H): 4CL6, (I): 4CL7, (J): 4CL9a, (K): 4CL9b, (L): 4CL9c) of tomato leaves (cv. Elpida) following plant exposure to cold stress $\left(5^{\circ} \mathrm{C}\right.$ for $\left.16 \mathrm{~h}\right)$ or inoculation $(20 \mathrm{~d})$ with either cucumber mosaic virus (CMV) or potato virus Y (PVY). Significant differences were determined by one-way ANOVA comparisons ( $p \leq 5 \%)$. Signif. codes: ns: non-significant; 0.05: ${ }^{*} ; 0.01:^{* *} ; 0.001:^{* * *} ; 0:{ }^{* * * *}$. 
Combined biotic (CMV or PVY) and abiotic (cold) stress triggered 4CL gene coding (Supplementary File S2). In this case, the noted upregulation was generally similar to the one induced by biotic stress alone (Supplementary File S2).

\subsection{Transcription of the Genes Coding for the Enzymes Primarily Regulating Flavonoid Synthesis} (CHS, FLS)

Following the core PBP, flavonoid synthesis is mainly mediated by CHS and FLS (Figure 1). The transcription of the genes encoding for these two enzymes was assessed. Cold stress or viral infection (CMV or PVY) largely stimulated the transcription of most genes encoding for CHS (Figure 5). In contrast to the transcription pattern of the PBP, the noted up-regulation was more pronounced following viral infection, as compared to exposure to cold stress (Figure 5). This sizeable shift in upregulation suggests that flavonoids are critical in virus-induced host responses.

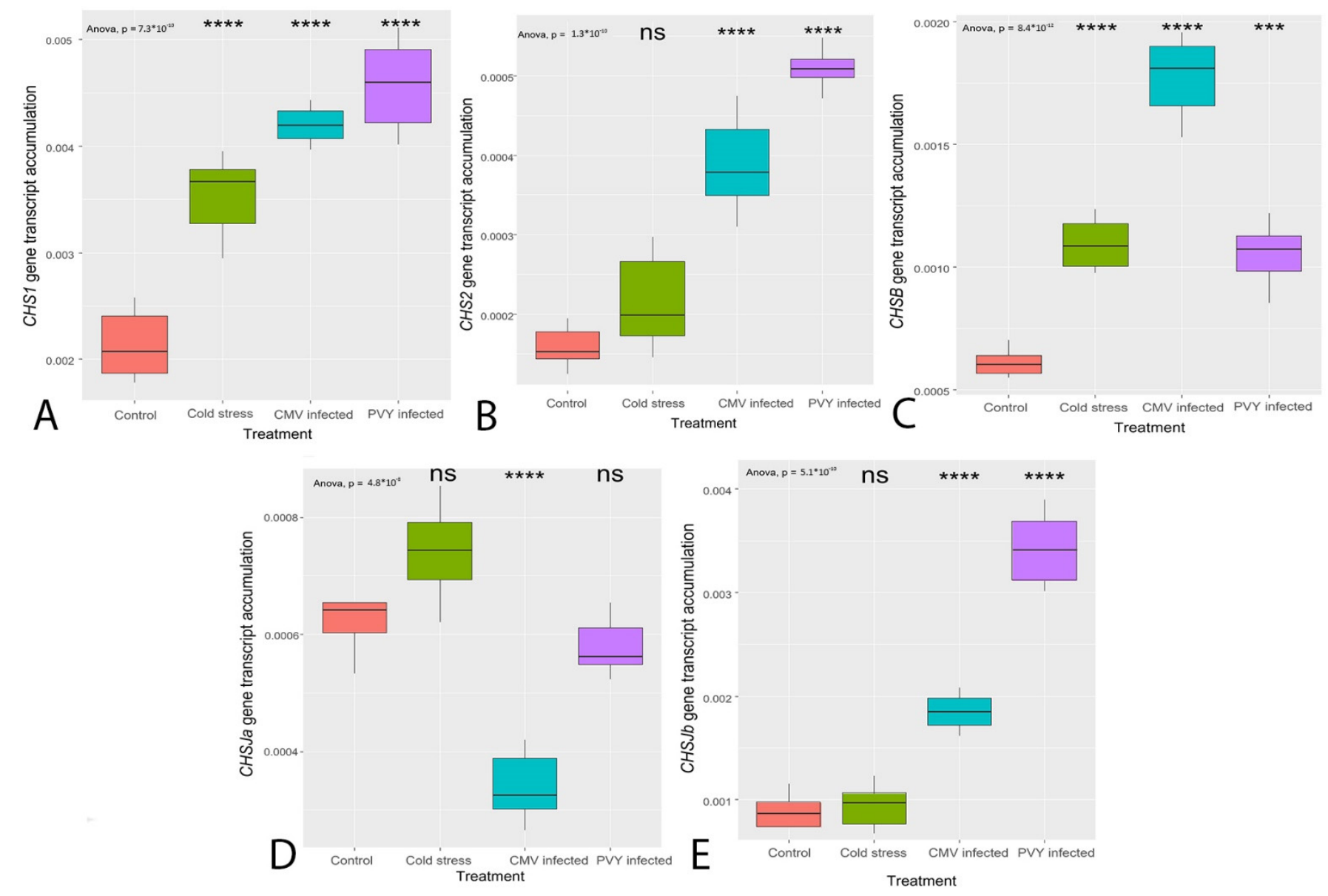

Figure 5. Transcription of the genes encoding for chalcone synthase (CHS) isoenzymes ((A): CHS1, (B): CHS2, (C): CHSB, (D): CHSJA, (E): CHSJB of tomato leaves (cv. Elpida) following plant exposure to cold stress ( $5^{\circ} \mathrm{C}$ for $16 \mathrm{~h}$ ) or inoculation (20 d) with either cucumber mosaic virus (CMV) or potato virus Y (PVY). Significant differences were determined by one-way ANOVA comparisons $(p \leq 5 \%)$. Signif. codes: ns: non-significant; $0.05:{ }^{*} ; 0.01:^{* *} ; 0.001:^{* * *} ; 0:^{* * * *}$.

Notably, combined biotic (CMV or PVY) and abiotic (cold) stress increased CHS1 gene transcription more than the one noted under single biotic stress (Supplementary File S2).

Cold stress or viral infection (CMV or PVY) initiated strong transcription in two (out of three) genes encoding for FLS (Figure 6). This triggering was more extended following viral infection (at least in the FLS1 isoform), as compared to cold stress exposure (Figure 6). 

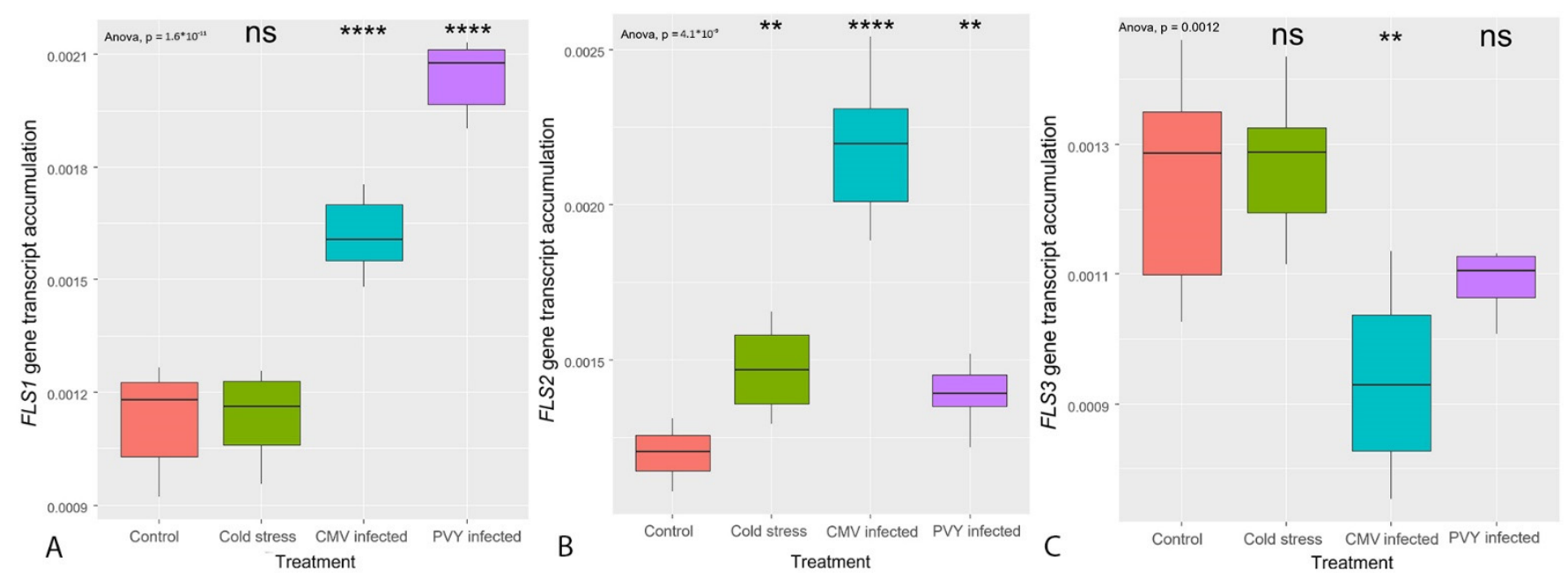

Figure 6. Transcription of the genes encoding for flavonol synthase (FLS) isoenzymes of tomato leaves (cv. Elpida) (A): FLS1, (B): FLS2, (C): FLS3) following plant exposure to cold stress $\left(5^{\circ} \mathrm{C}\right.$ for $\left.16 \mathrm{~h}\right)$ or inoculation $(20 \mathrm{~d})$ with either cucumber mosaic virus $(C M V)$ or potato virus $Y(P V Y)$. Significant differences were determined by one-way ANOVA comparisons $(p \leq 5 \%)$. Signif. codes: ns: non-significant; $0.05:{ }^{*} ; 0.01:^{* *} ; 0.001:{ }^{* *} ; 0: * * *$.

Combined biotic (CMV or PVY) and abiotic (cold) stress stimulated FLS1 gene transcription similarly to single biotic stress (Supplementary File S2).

\section{Discussion}

In agricultural environments, plants cope with multiple stresses, either sequential or simultaneously, which not only limit growth and productivity but also trigger (metabolic and transcriptional) reprogramming aiming to achieve homeostasis [31,32]. In plants, the phenylpropanoid biosynthetic pathway has been suggested to be vital for adaptation to the ever-changing, often stressful, environments [31]. The primary role of flavonoid biosynthesis was believed to be the protection against UV light, since such moieties can readily absorb it with great efficiency [33]. However, recent evidence revealed secondary flavonoid localization sites (including mesophyll, chloroplasts, vacuoles, and nucleus; [34]), and in this way rendering them as candidate molecules for protection of specific organelles against oxidative damage [35]. Notably, flavonoids also exhibit strong antimicrobial activity against pathogens, including viruses $[33,36]$. This activity is proposed to be attributed to either binding to the capsid proteins or direct inhibition of the viral polymerases, thus obstructing the viral infection [37].

Data of this study indicate that cold stress generally upregulated the transcription of most genes related to the core PBP, as well as genes participating in the flavonoid biosynthesis (Figures 3-6), which led to a corresponding increase in TP content, TF content, and PAL enzyme activity (Figure 2). In agreement, a substantial increase in TP and TF levels of Ocimum basilicum $\mathrm{L}$. leaves subjected to cold stress $\left(4^{\circ} \mathrm{C}\right.$ for $12 \mathrm{~h}$ ), and a corresponding increase in PAL enzyme activity and $\mathrm{C} 4 \mathrm{H}$ gene expression has been reported [38]. Similarly, cold stress $\left(10^{\circ} \mathrm{C}\right.$ for $\left.24 \mathrm{~h}\right)$ led to the induction of the $\mathrm{CHS}$ transcription in maize [39]. Moreover, low temperature $\left(10^{\circ} \mathrm{C}\right.$ for $\left.24 \mathrm{~h}\right)$ greatly induced several genes encoding for $4 \mathrm{CL}$ isoenzymes that catalyze the conversion of 4-coumaric acid, caffeic acid, and ferulic acid to their corresponding CoA esters. Hence, it can be deduced that channeling the metabolic flow towards the production of multiple phenylpropanoid metabolites from structural molecules (e.g., lignin) to metabolites with strong antioxidant activity contributes to the plasticity of the metabolic pathway in the ever-changing environmental stimuli [12,13,40-42]. In tomatoes, cold stress $\left(4^{\circ} \mathrm{C}\right.$ for $\left.24 \mathrm{~h}\right)$ significantly increased transcription of $4 C L$ genes [43], while the 4CL2 isoenzyme was recently associated with increased flavonoid production and antioxidant activity [44]. Recently, cold stress has also been associated with increased flavonoid accumulation, though a rather weak affinity between the metabolite and gene 
expression was noted. This suggests that important post-translational events influence the flavonoid biosynthesis, or the produced metabolites can be readily transposed [45]. The present report is in line with the stimulatory effect of cold stress on the phenylpropanoid biosynthetic pathway as well as the flavonoid biosynthesis.

Notably, applying combined biotic (CMV or PVY viral infection) and abiotic (cold) stress revealed a rather complementary effect on metabolite accumulation, PAL activity, and PBP key gene expression (Supplementary File S2). An exception to this trend was the $P A L$ transcription, exhibiting a priming-like effect. However, the reduced PAL transcription of the cold stressed-PVY infected plants did not result in reduced metabolite accumulation, indicating the complexity of the multi-level (transcriptional and post-transcriptional) regulation of PBP (Supplementary File S2). The observed regulation patterns owing to combined biotic and abiotic stress were different than those of polyamine biosynthesis and metabolism, where the regulation of some genes indicated the existence of a priming-like mechanism [21].

Moreover, our data also underline that viral infection (CMV or PVY) can also generally upregulate the transcription of most of the genes of the core PBP/flavonoid biosynthesis routes (Figures 3-6). Influence at a transcriptional level was significantly associated with a respective increase in TP content, TF levels, and PAL enzyme activity in comparison to the control (Figure 2). A similar trend of core PBP regulation has recently been noted in PVY infected potato leaves, while upregulation was associated with increased lignin synthesis [46]. Similarly, CMV viral infection stimulated the transcription of flavonoid related genes in Luffa cylindrical L. [47]. In agreement, substantial regulation of PAL gene expression and of genes associated with flavonoid biosynthesis was induced by Tomato Mosaic Virus (ToMV) infection in tomato leaves [48]. While in grapevines, Gutha et al. [49] revealed strong induction of PAL and CHS, as well as a significant increase in the flavonol accumulation in leaves infected with Grapevine Leafroll-associated Virus-3 (GLRaV-3) and exhibiting symptoms of grapevine leafroll disease (GLRD). Our study indicates, for the first time that the genes encoding for the flavonoid and flavonol biosynthesis clade enzymes (CHS, FLS) were favorably upregulated compared to genes/isoforms encoding for the core PBP enzymes (PAL, C4H, 4CL). These findings imply a possible role of flavonoids in the physiological responses against viral pathogens. Similar conclusions were recorded by Sade et al. [50] where an upregulation in the transcription of CHS and FLS genes was associated with a higher tolerance against the Tomato Yellow Leaf Curl Virus (TYLCV) viral infection

It was also evident that the effect of cold stress (abiotic) and viral infection (biotic) stresses on the regulation of different PBP clades fluctuates greatly. The former stressor mostly upregulated the transcription of the core PBP (especially for PAL, C4H, and 4CL2 multi gene family), whereas the latter increased the transcription of flavonoid biosynthesis (CHS and FLS genes) (Figures 3-6). In agreement, viral infections are reported to produce a less profound imprint on the cellular metabolism as compared to cold stress [19,51]. We postulate that the recorded differences in the TP and TF accumulation, owing to the stimulation of the core PBP (indicated by the increased transcription of $P A L, C 4 H$, and several $4 C L$ genes along with the increased PAL enzyme activity), results in an increased flow towards the production of antioxidant and protective metabolites such as flavonoids, even with a more constrained stimulation of the gene transcription of the flavonoid associated genes. The differential physiological reaction between cold stress (abiotic) and viral infection (biotic) stresses is rather analogous to the effects of the chronic (and milder) versus acute stresses (reviewed by Niinemets [52]). While chronic stress results in more constrained effects on the plant metabolism and precise responses, acute stress causes a rapid and more severe response.

The cold stress-induced transcriptional stimulation of several genes involved in flavonoid biosynthesis and flavonol (CHS1, CHS2b, CHSJa, and FLS2) (Figures 5 and 6) in combination with a more substantial increase in TF content as compared to viral infection suggesting that multiple parameters are involved in the respective regulation. These parameters can be (1) the duration of the stress, (2) the core PBP mobilization level (thus 
increased substrate availability for flavonoid biosynthesis), (3) the differential response of the genes encoding for various flavonoid biosynthesis isoenzymes, and (4) the regulation by post-translational modification of various key enzymes, that may act synergistically under unfavorable conditions for the timing and the magnitude of the stimulation of flavonoid biosynthesis.

\title{
5. Conclusions
}

In conclusion, we postulate that both cold stress and viral infection (CMV or PVY) activate the PBP, though they induce a differential effect on the regulation of the different clades/isoforms. The former upregulates mostly genes involved in core PBP (PAL, C4H, $4 \mathrm{CL}$ ), and led to increased TP and TF contents. The latter mostly affected the transcription of genes encoding for flavonoid biosynthesis enzymes (CHS, FLS), underlining their dual role as both antioxidants and anti-viral agents. Considering these differential responses our data provide novel insights into tomato stress tolerance which is highly important for providing the context for future breeding programs.

Supplementary Materials: The following are available online at https:/ /www.mdpi.com/article/10 $.3390 /$ horticulturae7110448/s1, Table S1. Above ground biomass. Table S2. Stem length. Table S3. Chlorophyll content. Table S4. Specific primers sequences of genes used for qPCR. File S1. Tests for normality. File S2. Total phenolic content, total flavonoid content, phenylalanine ammonia-lyase (PAL) activity, and expression levels of genes coding for enzymes participating in the phenylpropanoid biosynthetic pathway of tomato leaves (cv. Elpida) following plant exposure to cold stress $\left(5^{\circ} \mathrm{C}\right.$ for $16 \mathrm{~h}$; abiotic stress), inoculation ( $20 \mathrm{~d}$ ) with either cucumber mosaic virus (CMV) or potato virus $Y$ (PVY) (biotic stress), as well as inoculation with either CMV or PVY and then exposure to cold stress (combined biotic and abiotic stress). Significant differences were determined by one-way ANOVA comparisons $(p \leq 5 \%)$. Bars represent means ( $(\mathrm{SEM})$ of three biological replications. Figure S1. Phylogenetic analysis of tomato 4-coumarate-CoA ligase (4CL) proteins using the online tools of phylogeny.fr. Figure S2. Phylogenetic analysis of tomato chalcone synthase (CHS) proteins using the online tools of phylogeny.fr. Figure S3. Time-bar with the treatments of this experiment.

Author Contributions: Conceptualization, P.P. and G.T.; Methodology, P.P., N.N., A.Z. and G.T.; Data Curation, A.Z. phylogenetic analysis, P.P., N.N. and G.T.; Writing-Original Draft Preparation, P.P., N.N., D.F, A.Z., C.D. and G.T.; Writing-Review and Editing, P.P., N.N., D.F., A.Z., C.D. and G.T.; Visualization, N.N, C.D. and G.T.; Supervision, G.T.; Project Administration, P.P. and G.T. All authors have read and agreed to the published version of the manuscript.

Funding: This research received no external funding.

Institutional Review Board Statement: Not applicable.

Informed Consent Statement: Not applicable.

Data Availability Statement: Raw data are available upon request from the corresponding author.

Acknowledgments: We are grateful to the laboratory staff for their contributions, continued diligence, and dedication to their craft. The valuable comments of the editor and two anonymous reviewers are greatly appreciated.

Conflicts of Interest: The authors declare no conflict of interest.

\author{
Abbreviations \\ CHS chalcone synthase \\ CMV cucumber mosaic virus \\ $\mathrm{C} 4 \mathrm{H} \quad$ cinnamic acid 4-hydroxylase \\ FLS flavonol synthase \\ GLRaV-3 grapevine leafroll-associated virus 3
}




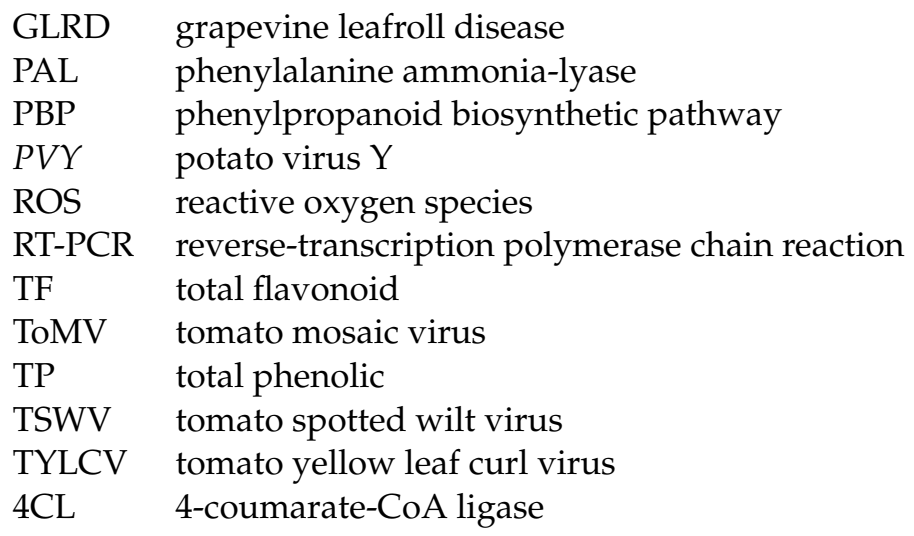

\section{References}

1. Vogt, T. Phenylpropanoid biosynthesis. Mol. Plant 2010, 3, 2-20. [CrossRef] [PubMed]

2. Hu, W.J.; Kawaoka, A.; Tsai, C.J.; Lung, J.; Osakabe, K.; Ebinuma, H.; Chiang, V.L. Compartmentalized expression of two structurally and functionally distinct 4-coumarate:CoA ligase genes in aspen (Populus tremuloides). Proc. Nat. Acad. Sci. USA 1998, 95, 5407-5412. [CrossRef] [PubMed]

3. Betz, C.; McCollum, T.G.; Mayer, R.T. Differential expression of two cinnamate 4-hydroxylase genes in "Valencia" orange (Citrus sinensis Osbeck). Plant. Mol. Biol. 2001, 46, 741-748. [CrossRef] [PubMed]

4. Yuan, Y.; Yu, S.; Yu, J.; Zhan, Z.; Li, M.; Liu, G.; Wang, X.; Huang, L. Predicting the Function of 4-Coumarate:CoA Ligase (LJ4CL1) in Lonicera japonica. Int. J. Mol. Sci. 2014, 15, 2386-2399. [CrossRef]

5. Li, Y.; Kim, J.I.; Pysh, L.; Chapple, C. Four isoforms of Arabidopsis 4-coumarate:CoA ligase have overlapping yet distinct roles in phenylpropanoid metabolism. Plant Physiol. 2015, 169, 2409-2421. [PubMed]

6. Lefevere, H.; Bauters, L.; Gheysen, G. Salicylic acid biosynthesis in plants. Front. Plant Sci. 2020, 11, 338. [CrossRef] [PubMed]

7. Panche, A.N.; Diwan, A.D.; Chandra, S.R. Flavonoids: An overview. J. Nutr. Sci. 2016, 5, e47. [CrossRef]

8. Kumar, S.; Pandey, A.K. Chemistry and biological activities of flavonoids: An overview. Sci. World J. 2013, 2013, 162750. [CrossRef]

9. Tohge, T.; Watanabe, M.; Hoefgen, R.; Fernie, A.R. The evolution of phenylpropanoid metabolism in the green lineage. Crit. Rev. Biochem. Mol. Biol. 2013, 48, 123-152. [CrossRef]

10. Zakaryan, H.; Arabyan, E.; Oo, A.; Zandi, K. Flavonoids: Promising natural compounds against viral infections. Arch. Virol. 2017, 162, 2539-2551. [CrossRef]

11. Šamec, D.; Karalija, E.; Šola, I.; Vujcic Bok, V.; Salopek-Sondi, B. The role of polyphenols in abiotic stress response: The influence of molecular structure. Plants 2021, 10, 118. [CrossRef] [PubMed]

12. Chatzistathis, T.; Fanourakis, D.; Aliniaeifard, S.; Kotsiras, A.; Delis, C.; Tsaniklidis, G. Leaf age-dependent effects of boron toxicity in two Cucumis melo varieties. Agronomy 2021, 11, 759. [CrossRef]

13. Chen, Y.; Fanourakis, D.; Tsaniklidis, G.; Aliniaeifard, S.; Yang, Q.; Li, T. Low UVA intensity during cultivation improves the lettuce shelf-life, an effect that is not sustained at higher intensity. Postharvest Biol. Technol. 2021, 172, 111376. [CrossRef]

14. Dixon, R.A.; Paiva, N.L. Stress-induced phenylpropanoid metabolism. Plant Cell 1995, 7, 1085-1097. [CrossRef]

15. Król, A.; Amarowiczb, R.; Weidnera, S. The effects of cold stress on the phenolic compounds and antioxidant capacity of grapevine (Vitis vinifera L.) leaves. J. Plant Physiol. 2015, 189, 97-104. [CrossRef] [PubMed]

16. Pellegrini, L.; Rohfritsch, O.; Fritig, B.; Legrand, M. Phenylalanine ammonia-lyase in tobacco: Molecular cloning and gene expression during the hypersensitive response to tobacco mosaic virus and the response to a fungal elicitor (fungi and wounding). Plant Physiol. 1994, 106, 877-886. [CrossRef]

17. Rivero, R.M.; Ruiz, J.M.; Garcia, P.C.; López-Lefebre, L.R.; Sánchez, E.; Romero, L. Resistance to cold and heat stress: Accumulation of phenolic compounds in tomato and watermelon plants. Plant Sci. 2001, 160, 315-321. [CrossRef]

18. Cushnie, T.P.T.; Lamb, A.J. Antimicrobial activity of flavonoids. Int. J. Antimicrob. Agents 2005, 26, 343-356. [CrossRef]

19. Gutiérrez-Albanchez, E.; Gradillas, A.; García, A.; García-Villaraco, A.; Gutierrez-Mañero, F.J.; Ramos-Solano, B. Elicitation with Bacillus QV15 reveals a pivotal role of $\mathrm{F} 3 \mathrm{H}$ on flavonoid metabolism improving adaptation to biotic stress in blackberry. PLoS ONE 2020, 15, e0232626. [CrossRef]

20. Fini, A.; Brunetti, C.; Di Ferdinando, M.; Ferrini, F.; Tattini, M. Stress-induced flavonoid biosynthesis and the antioxidant machinery of plants. Plant Signal. Behav. 2011, 6, 709-711. [CrossRef]

21. Tsaniklidis, G.; Pappi, P.; Tsafouros, A.; Charova, S.N.; Nikoloudakis, N.; Roussos, P.A.; Paschalidis, K.A.; Delis, C. Polyamine homeostasis in tomato biotic/abiotic stress cross-tolerance. Gene 2020, 727, 144230. [CrossRef] [PubMed]

22. Mumford, A.; Barker, I.; Wood, K.R. The detection of tomato spotted wilt virus using the polymerase chain reaction. J. Virol. Met. 1994, 46, 303-311. [CrossRef]

23. Faggioli, F.; Ferretti, L.; Albanese, G.; Sciarroni, R.; Pasquini, G.; Lumia, V.; Barba, M. Distribution of olive tree viruses in Italy as revealed by one-step RT-PCR. J. Plant Pathol. 2005, 87, 49-55. 
24. Dovas, C.I.; Efthimiou, K.; Katis, N.I. Generic detection and differentiation of tobamoviruses by a spot nested RTPCR-RFLP using dI-containing primers along with homologous dG-containing primers. J. Virol. Meth. 2004, 117, 137-144. [CrossRef] [PubMed]

25. Nie, X. Reverse transcription loop-mediated isothermal amplification of DNA for detection of potato virus Y. Plant Disease 2005, 89, 605-610. [CrossRef]

26. Singleton, V.L.; Orthofer, R.; La Muela-Raventos, R.M. Analysis of total phenols and other oxidation substrates and antioxidants by means of Folin-Cocalteu reagent. Methods Enzymol. 1999, 299, 152-178.

27. Aryal, S.; Baniya, M.K.; Danekhu, K.; Kunwar, P.; Gurung, R.; Koirala, N. Total phenolic content, flavonoid content and antioxidantpotential of wild vegetables from Western Nepal. Plants 2019, 8, 96. [CrossRef]

28. Assis, J.S.; Maldonado, R.; Munoz, T.; Escribano, M.I.; Merodio, C. Effect of high carbon dioxide concentration on PAL activity and phenolic contents in ripening cherimoya fruit. Postharvest Biol. Technol. 2001, 23, 33-39. [CrossRef]

29. Maliogka, V.I.; Olmos, A.; Pappi, P.G.; Lotos, L.; Efthimiou, K.; Grammatikaki, G.; Thierry Candresse, T.; Katis, N.I.; Avgelis, A.D. A novel grapevine badnavirus is associated with the Roditis leaf discoloration disease. Virus Res. 2015, 203, 47-55. [CrossRef]

30. Dereeper, A.; Guignon, V.; Blanc, G.; Audic, S.; Buffet, S.; Chevenet, F.; Dufayard, J.-F.; Guindon, S.; Lefort, V.; Lescot, M.; et al. Phylogeny.fr: Robust phylogenetic analysis for the non-specialist. Nucleic Acids Res. 2008, 36, W465-W469. [CrossRef]

31. Atkinson, N.J.; Urwin, P.E. The interaction of plant biotic and abiotic stresses: From genes to the field. J. Exp. Bot. 2012, 63, 3523-3543. [CrossRef] [PubMed]

32. Tsaniklidis, G.; Chatzistathis, T.; Fanourakis, D.; Nikoloudakis, N.; Kotsiras, A.; Delis, C.; Tzortzakakis, E.A. Leaf antioxidant machinery stimulation by Meloidogyne javanica infestation: A case study on Cucumis melo seedlings. Plant Stress 2021, 1, 100002. [CrossRef]

33. Sharma, A.; Shahzad, B.; Rehman, A.; Bhardwaj, R.; Landi, M.; Zheng, B. Response of phenylpropanoid pathway and the role of polyphenols in plants under abiotic stress. Molecules 2019, 24, 2452. [CrossRef] [PubMed]

34. Agati, G.; Brunetti, C.; Fini, A.; Gori, A.; Guidi, L.; Landi, M.; Sebastiani, F.; Tattini, M. Are flavonoids effective antioxidants in plants? Twenty years of our investigation. Antioxidants 2020, 9, 1098. [CrossRef] [PubMed]

35. Agati, G.; Azzarello, E.; Pollastri, S.; Tattini, M. Flavonoids as antioxidants in plants: Location and functional significance. Plant Sci. 2012, 196, 67-76. [CrossRef] [PubMed]

36. Harborne, J.B.; Williams, C.A. Advances in flavonoid research since 1992. Phytochemistry 2000, 55, 481-504. [CrossRef]

37. Selway, J.W.T. Antiviral activity of flavones and flavans. In Plant Flavonoids in Biology and Medicine: Biochemical, Pharmacological, and Structure-Activity Relationships, Proceedings of the a Symposium Held in Buffalo, New York, NY, USA, 22-26 July 1985; Cody, V., Middleton, E., Harborne, J.B., Eds.; Alan R. Liss Inc.: New York, NY, USA, 1986; pp. 521-536.

38. Rezaie, R.; Abdollahi Mandoulakani, B.; Fattahi, M. Cold stress changes antioxidant defense system, phenylpropanoid contents and expression of genes involved in their biosynthesis in Ocimum basilicum L. Sci. Rep. 2020, 10, 5290. [CrossRef]

39. Christie, P.J.; Alfenito, M.R.; Walbot, V. Impact of low-temperature stress on general phenylpropanoid and anthocyanin pathways: Enhancement of transcript abundance and anthocyanin pigmentation in maize seedlings. Planta 1994, 194, 541-549. [CrossRef]

40. Schneider, K.; Hövel, K.; Witzel, K.; Hamberger, B.; Schomburg, D.; Kombrink, E.; Stuible, H.P. The substrate specificitydetermining amino acid code of 4-coumarate:CoA ligase. Proc. Natl. Acad. Sci. USA 2003, 100, 8601-8606. [CrossRef]

41. Cao, Y.; Han, Y.; Li, D.; Lin, Y.; Cai, Y. Systematic analysis of the 4-Coumarate:Coenzyme A Ligase (4CL) related genes and expression profiling during fruit development in the Chinese Pear. Genes 2016, 7, 89. [CrossRef]

42. Lavhale, S.G.; Kalunke, R.M.; Giri, A.P. Structural, functional and evolutionary diversity of 4-coumarate-CoA ligase in plants. Planta 2018, 248, 1063-1078. [CrossRef] [PubMed]

43. Duan, X.; Chen, X.; Wang, S.; Zhang, X. Transcriptome sequencing and analysis of chilling tolerance mutant tomato under low temperature. Russ. J. Plant Physiol. 2019, 66, 110-118. [CrossRef]

44. Tao, X.; Wu, Q.; Aalim, H.; Li, L.; Mao, L.; Luo, Z.; Ying, T. Effects of exogenous abscisic acid on bioactive components and antioxidant capacity of postharvest tomato during ripening. Molecules 2020, 25, 1346. [CrossRef]

45. Schulz, E.; Tohge, T.; Zuther, E.; Fernie, A.R.; Hincha, D.K. Flavonoids are determinants of freezing tolerance and cold acclimation in Arabidopsis Thaliana. Sci. Rep. 2016, 6, 34027. [CrossRef]

46. Kogovšek, P.; Pompe-Novak, M.; Petek, M.; Fragner, L.; Weckwerth, W.; Gruden, K. Primary metabolism, phenylpropanoids and antioxidant pathways are regulated in potato as a response to Potato virus Y infection. PLoS ONE 2016, 11, e0146135. [CrossRef]

47. Lou, L.N.; Su, X.J.; Liu, X.H.; Liu, Z. Transcriptome analysis of Luffa cylindrica (L.) Roem response to infection with Cucumber mosaic virus $(C M V)$. Gene 2020, 737, 144451. [CrossRef] [PubMed]

48. Aseel, D.G.; Rashad, Y.; Hammad, S.M. Arbuscular mycorrhizal fungi trigger transcriptional expression of flavonoid and chlorogenic acid biosynthetic pathways genes in tomato against Tomato Mosaic Virus. Sci. Rep. 2019, 9, 9692. [CrossRef]

49. Gutha, L.R.; Casassa, L.F.; Harbertson, J.F.; Naidu, R.A. Modulation of flavonoid biosynthetic pathway genes and anthocyanins due to virus infection in grapevine (Vitis vinifera L.) leaves. BMC Plant Biol. 2010, 10, 187. [CrossRef] [PubMed]

50. Sade, D.; Shriki, O.; Cuadros-Inostroza, A.; Tohge, T.; Semel, Y.; Haviv, Y.; Willmitzer, L.; Fernie, A.R.; Czosnek, H.; Brotman, Y. Comparative metabolomics and transcriptomics of plant response to Tomato yellow leaf curl virus infection in resistant and susceptible tomato cultivars. Metabolomics 2015, 11, 81-97. [CrossRef] 
51. Fernández-Calvino, L.; Osorio, S.; Hernández, M.L.; Hamada, I.B.; Del Toro, F.J.; Donaire, L.; Yu, A.; Bustos, R.; Fernie, A.R.; Martínez-Rivas, J.M. Virus-induced alterations in primary metabolism modulate susceptibility to Tobacco rattle virus in Arabidopsis. Plant Physiol. 2014, 166, 1821-1838. [CrossRef] [PubMed]

52. Niinemets, U. Mild versus severe stress and BVOCs: Thresholds, priming and consequences. Trends Plant Sci. 2010, 15, 145-153. [CrossRef] [PubMed] 